\title{
JOHN FINNIS:
}

\section{Prirodzený zákon a prirodzené práva}

Bratislava: Kalligram 2019, 712 s.

V roku 2019 vo vydavatel'stve Kalligram vyšiel slovenský preklad knihy Johna M. Finnisa Prirodzený zákon a prirodzené práva. Táto práca si zaslúži pozornost', pretože autor sa v nej pokúša zdôvodnit' l'udské formy dobra, blaho a spôsob ich identifikácie prostredníctvom teórie prirodzeného zákona, čo v istom zmysle môže obohatit' diskusiu o univerzálnosti l’udských práv z pohladu liberálnej politickej filozofie.

Publikácia je rozdelená do troch častí a trinástich kapitol. Prvá čast' sa zaoberá metodologickými otázkami a filozoficko-historickými interpretáciami teórie prirodzeného zákona, jej právnej platnosti a vzt’ahu k morálke či sociálnej praxi. Druhá čast' analyzuje tradičné koncepty teórie prirodzeného zákona: základné l’udské formy dobra (život, poznanie, hra, estetický zážitok, priatel'stvo, praktická rozumnost' a náboženstvo), základné požiadavky praktickej rozumnosti, spoločné dobro, spravodlivost', práva, autoritu, právo, záväzok a nespravodlivé zákony. V tretej časti sa zaoberá vzt'ahom prírody, rozumom a Bohom.

Finnis vychádza z niekol'kých predpokladov, ktoré vymedzujú filozofické mantinely jeho uvažovania. $\mathrm{V}$ prvom rade na viacerých miestach zdôrazňuje, že štátom prijaté normy, ktoré majú poskytovat' sociálne techniky na riešenie sporov, odmieta, pretože fakty nemožno preukázat' a prezentovat' bez vyhodnotenia a pochopenia toho, čo je skutočne dobré pre l'udí. Sociálne vedy, psychológia, antropológia či metafyzické pozorovanie alebo posudzovanie nie sú schopné pochopit' a definovat' l'udskú prirodzenost', pretože každé indivíduum l'udskú prirodzenost' zakúša zvnútra vo forme vlastných sklonov. $Z$ tohto dôvodu ani nie je možné nejakým spôsobom zdôvodnit' l'udské formy dobra. „Človek skôr v rámci jednoduchého neodvodzujúceho aktu porozumenia pochopí, že predmet sklonu, ktorý zakúša, je prípadom všeobecnej formy dobra pre neho (aj pre iných, ktorí sú mu podobní)“ (s. 78). Okrem toho Finnis predpokladá, že to, čo je súčast'ou l'udskej prirodzenosti, sa jednoducho riadi rozumom, pretože človek má úsudok, vd'aka ktorému je schopný rozlíšit' príjemné od škodlivého. „V súlade s l'udskou prirodzenost'ou [conveniens humanae naturae] je riadit' sa správne utvoreným úsudkom (...) A čokol'vek je zjavne v rozpore s týmto úsudkom, to sa podobne chápe, že je proti zákonu prirodzenosti, a to prirodzenosti 
l’udskej“ (s. 91). Finnis teda rozpracúva teóriu prirodzeného zákona ako teóriu racionálnych základov morálneho úsudku racionálneho a autonómneho človeka, na ktorú sa odvoláva naprieč celým dielom.

Vzhl'adom na uvedené predpoklady je táto publikácia príspevkom $\mathrm{k}$ liberálnemu pochopeniu l’udských práv, čoho dôkazom sú rozsiahle časti, ktoré sa zaoberajú problematikou spravodlivosti, autority, práva či úlohami zákonov a záväzkov. Prínos a originálnost' autorovho prístupu sú v tom, že spája liberálny dôraz na autonómiu a neutrálnu a zjavnú teóriu l'udských dobier, ktorú rozpracoval Tomáš Akvinský, zatial' čo na všeobecne známe teórie prirodzeného zákona nekladie dôraz, alebo je voči nim kritický (napr. voči Kantovi na s. 519, 552 - 553, 557 či na s. 610).

Z hl'adiska rozsahu najpodstatnejšou čast'ou je druhá čast', v ktorej Finnis formuluje okrem iného sedem základných hodnôt (resp. l'udských dobier): život, poznanie, hra, estetický zážitok, priatel'stvo, praktická rozumnost' a náboženstvo. Autor ich základnú hodnotu odvodzuje zo sebadôkazu, pretože, žiadny rozumný a inteligentný človek nebude súhlasit's tvrdením, podl'a ktorého poznanie, priatel'stvo, život či spravodlivost' nie sú l'udskou formou dobier. Čiže ak akýkol'vek človek splńa podmienku praktickej rozumnosti, potom je schopný príst' k rovnakým záverom. Toto vyvoláva zásadné filozofické otázky a to, či je možné na základe praktickej rozumnosti určit' tento zoznam dobier, alebo ako ich z individuálnej úrovne možno akceptovat' ako spoločné dobro. Tento nedostatok je zrejmý napríklad v prípade prvej l'udskej formy dobra - poznania: poznávam preto, lebo som dospel prostredníctvom praktickej rozumnosti $\mathrm{k}$ tomuto záveru, a preto ide o základnú hodnotu. Finnis tvrdí, že dobro poznania je samozrejmé, zjavné. Nemožno ho dokázat', no žiadny dôkaz ani nepotrebuje (s. 120, 125, 147). Takýto spôsob argumentácie zahmlieva a nedostatočne zdôvodňuje jeho záver, prečo poznanie je základnou l’udskou formou dobra samo osebe. Podobne vyznievajú kontraproduktívne autorove tvrdenia, podl’a ktorých priatel'stvo je základnou l'udskou formou dobra, ked’že prispieva k sebanapínaniu a sebauskutočňovaniu a vzájomnému utváraniu medzi zainteresovanými subjektmi (s. 225). Autorov záver o nestrannom pohl'ade, pohl'ade $\mathrm{z}$ tretieho hl'adiska, jedinečnom pohl'ade, z ktorého je rovnako „v zornom poli“ a „,v hre“ vlastné i priatel'ovo dobro (s. 228), je prinajmenšom idealistické, pretože vylúčenie ,vlastného“ alebo ,priatel’ovho“ hl'adiska vytvára dojem, akoby pravé priatel'stvo bolo nezávislé od sociálnych záujmov zúčastnených aktérov. To je však nedostatočne zdôvodnený záver, prečo priatel'stvo založené na „nestrannom“ pohl'ade je základnou l'udskou formou dobra a prečo iný druh priatel'stva ním nemôže byt'.

Finnis odmieta pokusy hierarchizovat' spomínané základné l'udské formy dobra, pretože každé z nich sa dá pokladat' za najdôležitejšie (s. 157, 174). Zároveň však tvrdí, že praktická rozumnost' je jedným zo základných dobier, vd’aka ktorému má 
človek účast' na ostatných základných dobrách a riadi sa ním pri svojich osobných záväzkoch, pri výbere projektov a pri ich realizácii (s. 168). Praktická rozumnost’ je základným aspektom l'udského blaha, pričom sa zaoberá aj „účast’ou človeka na všetkých (ostatných) základných aspektoch l'udského blaha. Preto sa jej požiadavky zaoberajú plnost'ou blaha“" (s. 170 - 171). Tento koncept praktickej rozumnosti však možno uplatnit' iba na zrelých, inteligentných, skúsenost'ou rozumných, vnútorne vyrovnaných či túžbami alebo vášňami neovplyvnených l’udí, čo značne obmedzuje rozsah l'udí, ktorí sú schopní dospiet' prostredníctvom usudzovania k poznaniu týchto základných dobier, alebo luudí, ktorých sa tieto dobrá týkajú. Finnis proti tejto námietke argumentuje tým, že pri posudzovaní špecifických práv istých osôb by sa mal brat' do úvahy určitý vzorec či rozsah vzorcov l'udského charakteru, správania a interakcie v spoločenstve, ktorý by mal prispievat' $\mathrm{k}$ individuálnemu rozvoju (s. 335). Rovnako Finnis odmieta, aby akékolvek rozhodovanie autority bolo interpretované ako súdenie o inom človeku, že sa mýli, a že konanie podriadených si zaslúži len pohŕdanie a preferovanie vlastných záujmov autority (s. 340). Napriek tomu v deviatej kapitole rozpracúva politickú teóriu autority, podl'a ktorej autorita zohráva dôležitú úlohu pri riešení rozsiahlych koordinačných problémov jednomysel'ným rozhodovaním (s. 356), prispieva k lepšiemu plneniu vytýčených ciel’ov (s. 353 - 354), či disponuje vyššie spomínanými l’udskými vlohami (s. 371, 380). Problémom tejto teórie je, že $\mathrm{v}$ rámci politického uplatnenia zakotvuje l’udské práva na základe racionálnej spôsobilosti autority a kladie dôraz na ich univerzálnu nemennú platnost', zatial' čo ignoruje ich sociálne uznanie a ich pluralitnú povahu.

Na záver treba zdôraznit', že táto publikácia je obsiahla a z hl'adiska použitých zdrojov je zrejmé, že autor má $\mathrm{v}$ danej problematike pozoruhodný prehl'ad. $\mathrm{V}$ tomto zmysle sú užitočné aj poznámky na konci každej kapitoly, ktoré zahŕňajú odkazy na autorov, zaoberajúcich sa problematikou prirodzeného zákona. Napriek vyššie uvedeným výhradám túto publikáciu ocení najmä čitatel', ktorý sa zaoberá filozofiou Tomáša Akvinského, alebo problematikou zdôvodnenia ludských práv z pohl'adu prirodzeného zákona.

Martin Foltin

Martin Foltin

Filozofický ústav SAV

Klemensova 19

81364 Bratislava 1

Slovenská republika

e-mail: mart.foltin@gmail.com

ORCID ID: https://orcid.org/0000-0003-3981-7811 